\title{
Thermal Decomposition and Kinetic Analysis of Relaxor Ferroelectric Lead Magnesium Niobate
}

\author{
Chung-Hsin $\mathrm{Lu}^{*}$ and Cheng-Yen Wen \\ Department of Chemical Engineering, National Taiwan University, Taipei, Taiwan
}

(Received 24 November 1997; accepted 16 February 1998)

\begin{abstract}
The reaction mechanisms and kinetics of thermal decomposition of the relaxor ferroelectric $\mathrm{Pb}\left(\mathrm{Mg}_{1 / 3} \mathrm{Nb}_{2 / 3}\right) \mathrm{O}_{3}$ powder at elevated-temperatures have been investigated. The decomposition of $\mathrm{Pb}\left(\mathrm{Mg}_{1 / 3} \mathrm{Nb}_{2 / 3}\right) \mathrm{O}_{3}$ is characterized by an initial formation of pyrochlore phase, associated with evaporation of $\mathrm{PbO}$. Then pyrochlore phase subsequently gets dissociated, resulting in the formation of $\mathrm{Mg}_{4} \mathrm{Nb}_{2} \mathrm{O}_{9}$ and $\mathrm{MgNb}_{2} \mathrm{O}_{6}$. The decomposition amounts of $\mathrm{Pb}\left(\mathrm{Mg}_{1 / 3} \mathrm{Nb}_{2 / 3}\right) \mathrm{O}_{3}$ as well as pyrochlore phase increase monotonously with increase in the reaction temperature and time. Based on the isothermal analysis of reaction kinetics, the rate-controlling step for decomposition of $\mathrm{Pb}\left(\mathrm{Mg}_{1 / 3} \mathrm{Nb}_{2 / 3}\right) \mathrm{O}_{3}$ is determined to be the chemical reaction of $\mathrm{Pb}\left(\mathrm{Mg}_{1 / 3} \mathrm{Nb}_{2 / 3}\right) \mathrm{O}_{3}$ itself with activation energy of $234 \mathrm{~kJ} \mathrm{~mol}^{-1}$. On the other hand, during the decomposition of pyrochlore phase, a molten microstructure is formed, and reaction kinetics changes greatly. This decomposition of pyrochlore phase is confirmed to be a first-order reaction with higher activation energy of $407 \mathrm{~kJ} \mathrm{~mol}^{-1}$. (C) 1998 Elsevier Science Limited. All rights reserved
\end{abstract}

\section{Introduction}

Lead magnesium niobate $\left(\mathrm{Pb}\left(\mathrm{Mg}_{1 / 3} \mathrm{Nb}_{2 / 3}\right) \mathrm{O}_{3}\right)$, one of the representative materials in the family of relaxor ferroelectrics, has been known to possess high permittivity, high electric resistivity, and diffuse phase transition characteristics. Due to its excellent dielectric and piezoelectric characteristics, this material has been intensively investigated for its applications in multilayer capacitors and electrostrictive actuators. ${ }^{1-11}$ The major problem

*To whom correspondence should be addressed. encountered in the synthesis of $\mathrm{Pb}\left(\mathrm{Mg}_{1 / 3} \mathrm{Nb}_{2 / 3}\right) \mathrm{O}_{3}$ is that a pure perovskite compound is difficult to obtain. During the preparation of $\mathrm{Pb}\left(\mathrm{Mg}_{1 / 3} \mathrm{Nb}_{2 / 3}\right) \mathrm{O}_{3}$, the pyrochlore phases are often concomitantly formed along with $\mathrm{Pb}\left(\mathrm{Mg}_{1 / 3} \mathrm{Nb}_{2 / 3}\right) \mathrm{O}_{3}{ }^{12,13}$ In order to eliminate these pyrochlore phases, many research groups have focused their studies towards developing new synthetic processes for preparing pure $\mathrm{Pb}\left(\mathrm{Mg}_{1 / 3} \mathrm{Nb}_{2 / 3}\right) \mathrm{O}_{3}$. The columbite process, ${ }^{14,15}$ which uses pre-reacted $\mathrm{MgNb}_{2} \mathrm{O}_{6}$ precursors, has been recognized to be an effective solid-state reaction process for synthesizing $\mathrm{Pb}\left(\mathrm{Mg}_{1 / 3} \mathrm{Nb}_{2 / 3}\right) \mathrm{O}_{3}$. Other solution routes such as the precipitation, ${ }^{16,17}$ sol-gel, ${ }^{18,19}$ molten-salt, ${ }^{20,21}$ and hydrothermal ${ }^{22}$ processes have also been successfully developed.

Although monophasic $\mathrm{Pb}\left(\mathrm{Mg}_{1 / 3} \mathrm{Nb}_{2 / 3}\right) \mathrm{O}_{3}$ can be successfully synthesized, the evaporation of $\mathrm{PbO}$ during sintering is another major problem that greatly affects the application of this material. Due to low sinterability of $\mathrm{Pb}\left(\mathrm{Mg}_{1 / 3} \mathrm{Nb}_{2 / 3}\right) \mathrm{O}_{3}$, it is essential to sinter $\mathrm{Pb}\left(\mathrm{Mg}_{1 / 3} \mathrm{Nb}_{2 / 3}\right) \mathrm{O}_{3}$ at elevated temperatures. ${ }^{23,24}$ It has been shown that the hightemperature heating causes the volatilization of $\mathrm{PbO}$ from $\mathrm{Pb}\left(\mathrm{Mg}_{1 / 3} \mathrm{Nb}_{2 / 3}\right) \mathrm{O}_{3}$, and thereby brings about the thermal decomposition of $\mathrm{Pb}\left(\mathrm{Mg}_{1 / 3} \mathrm{Nb}_{2 / 3}\right)$ $\mathrm{O}_{3}{ }^{25}$ This decomposition of $\mathrm{Pb}\left(\mathrm{Mg}_{1 / 3} \mathrm{Nb}_{2 / 3}\right) \mathrm{O}_{3}$ in turn gives rise to the formation of pyrochlore phase and some other secondary compounds. The slight rotation of $\mathrm{BO}_{6}$ octahedra in $\mathrm{Pb}\left(\mathrm{Mg}_{1 / 3} \mathrm{Nb}_{2 / 3}\right) \mathrm{O}_{3}$ is responsible for the generation of pyrochlore phase. ${ }^{26}$ Due to the low dielectric perimittivity of pyrochlore phase, its presence is greatly detrimental to the dielectric properties of $\mathrm{Pb}\left(\mathrm{Mg}_{1 / 3} \mathrm{Nb}_{2 / 3}\right) \mathrm{O}_{3}$ itself. ${ }^{27,28}$ Consequently, maintaining the perovskite structure of $\mathrm{Pb}\left(\mathrm{Mg}_{1 / 3} \mathrm{Nb}_{2 / 3}\right) \mathrm{O}_{3}$ during sintering is extremely crucial for improving its dielectric properties.

For adjusting the heating conditions of $\mathrm{Pb}\left(\mathrm{Mg}_{1 / 3^{-}}\right.$ $\left.\mathrm{Nb}_{2 / 3}\right) \mathrm{O}_{3}$, a fundamental understanding of the decomposition behavior of $\mathrm{Pb}\left(\mathrm{Mg}_{1 / 3} \mathrm{Nb}_{2 / 3}\right) \mathrm{O}_{3}$ is very important. The primary purpose of this study 
was therefore to elucidate the decomposition mechanisms and reaction kinetics of $\mathrm{Pb}\left(\mathrm{Mg}_{1 / 3} \mathrm{Nb}_{2 / 3}\right) \mathrm{O}_{3}$ powder. During the decomposition of $\mathrm{Pb}\left(\mathrm{Mg}_{1 / 3} \mathrm{Nb}_{2 / 3}\right) \mathrm{O}_{3}$, pyrochlore phase was noted to be formed first and subsequently decomposed. In order to analyze the reaction kinetics of the above two serial decomposition reactions, the conversion ratios of $\mathrm{Pb}\left(\mathrm{Mg}_{1 / 3^{-}}\right.$ $\left.\mathrm{Nb}_{2 / 3}\right) \mathrm{O}_{3}$ and pyrochlore phase werc calculated separately. Different types of reaction models were utilized to fit the decomposition behavior of each reaction, and the rate-controlling processes and the activation energies were also determined.

\section{Experimental Procedure}

The $\mathrm{Pb}\left(\mathrm{Mg}_{1 / 3} \mathrm{Nb}_{2 / 3}\right) \mathrm{O}_{3}$ powder was prepared according to a modified columbite precursor method. ${ }^{15}$ Reagent-grade raw materials viz. $\mathrm{PbO}$, $\mathrm{MgO}$, and $\mathrm{Nb}_{2} \mathrm{O}_{5}$ were used. For accurately weighting $\mathrm{MgO}$, the $\mathrm{MgO}$ powder was heated to $800^{\circ} \mathrm{C}$ for half an hour to eliminate the $\mathrm{CO}_{2}$ and $\mathrm{H}_{2} \mathrm{O}$ absorbed on the particle surfaces. After weighing according to the desired stoichiometry, $\mathrm{Nb}_{2} \mathrm{O}_{5}$ and $\mathrm{MgO}$ were mixed in ethyl alcohol by ball-milling for $48 \mathrm{~h}$. The mixtures were dried and pressed to form pellets. After heating the pellets at $800^{\circ} \mathrm{C}$ for $2 \mathrm{~h}$, the columbite compound- $\mathrm{MgNb}_{2} \mathrm{O}_{6}$ was formed. This $\mathrm{MgNb}_{2} \mathrm{O}_{6}$ was then mixed with a stoichiometric amount of $\mathrm{PbO}$ in the same way as described above. The mixtures were dried and calcined at $900^{\circ} \mathrm{C}$ for $2 \mathrm{~h}$. After calcination, monophasic $\mathrm{Pb}\left(\mathrm{Mg}_{1 / 3} \mathrm{Nb}_{2 / 3}\right) \mathrm{O}_{3}$ powder, without any contents of pyrochlore phase, was obtained. This powder was then used for the following decomposition experiments.

The $\mathrm{Pb}\left(\mathrm{Mg}_{1 / 3} \mathrm{Nb}_{2 / 3}\right) \mathrm{O}_{3}$ powder was heated in a temperature-controlled furnace at temperatures ranging from $1150^{\circ} \mathrm{C}$ to $1300^{\circ} \mathrm{C}$ for different reaction time. After the reaction time was reached, the samples were quenched in air, and the weight loss during the heating process was measured. The compounds formed in the heated samples were analyzed by X-ray diffraction (XRD) using copper radiation. The relative contents of the compounds present in the samples were semi-quantitatively determined from the intensity of XRD peaks by using the following equation:

$$
\begin{aligned}
& \text { Content of compound } i(\%)= \\
& \frac{\text { Intensity of the major peak of compound } i}{\sum_{i} \text { Intensity of the major peak of compound } i}
\end{aligned}
$$

The (110) plane of $\mathrm{Pb}\left(\mathrm{Mg}_{1 / 3} \mathrm{Nb}_{2 / 3}\right) \mathrm{O}_{3}$, (222) plane of pyrochlore phase, (104) plane of $\mathrm{Mg}_{4} \mathrm{Nb}_{2} \mathrm{O}_{9}$, and (131) plane of $\mathrm{MgNb}_{2} \mathrm{O}_{6}$ were used for calculation. Variations in the microstructures of the heated samples during decomposition processes were examined by scanning electron microscopy (SEM). As for the analysis of reaction kinetics, the details concerning the calculation of decomposition ratios of $\mathrm{Pb}\left(\mathrm{Mg}_{1 / 3} \mathrm{Nb}_{2 / 3}\right) \mathrm{O}_{3}$ and pyrochlore phase after heat-treatment are described in Section 3.1 and 3.2 , respectively.

\section{Results and Discussion}

\subsection{Decomposition reactions of $\mathrm{Pb}\left(\mathrm{Mg}_{1 / 3} \mathrm{Nb}_{2 / 3}\right) \mathrm{O}_{3}$}

The X-ray diffraction spectra of $\mathrm{Pb}\left(\mathrm{Mg}_{1 / 3} \mathrm{Nb}_{2 / 3}\right) \mathrm{O}_{3}$ powder heated at various temperatures for $30 \mathrm{~min}$ are presented in Fig. 1. The corresponding spectrum of pure $\mathrm{Pb}\left(\mathrm{Mg}_{1 / 3} \mathrm{Nb}_{2 / 3}\right) \mathrm{O}_{3}$ is also shown in this figure for comparison [see Fig. 1(a)]. It is observed that, after heating at $1200^{\circ} \mathrm{C}$ for $30 \mathrm{~min}$, a new compound exhibiting a pyrochlore phase is formed. At $1250^{\circ} \mathrm{C}$-heating, the amount of $\mathrm{Pb}\left(\mathrm{Mg}_{1 / 3} \mathrm{Nb}_{2 / 3}\right) \mathrm{O}_{3}$ significantly decreases, associated with the corresponding increase in the amount of pyrochlore phase. Another new product $-\mathrm{Mg}_{4} \mathrm{Nb}_{2} \mathrm{O}_{9}$ is also produced along with pyrochlore phase at this stage. At $1300^{\circ} \mathrm{C}, \mathrm{Pb}\left(\mathrm{Mg}_{1 / 3^{-}}\right.$ $\left.\mathrm{Nb}_{2 / 3}\right) \mathrm{O}_{3}$ disappears entirely, and the products remaining in the sample are pyrochlore phase, $\mathrm{Mg}_{4} \mathrm{Nb}_{2} \mathrm{O}_{9}$, and $\mathrm{MgNb}_{2} \mathrm{O}_{6}$. The above results reveal that heating at elevated temperaturcs results in the decomposition of $\mathrm{Pb}\left(\mathrm{Mg}_{1 / 3} \mathrm{Nb}_{2 / 3}\right) \mathrm{O}_{3}$, accompanied with the formation of several types of secondary phases.

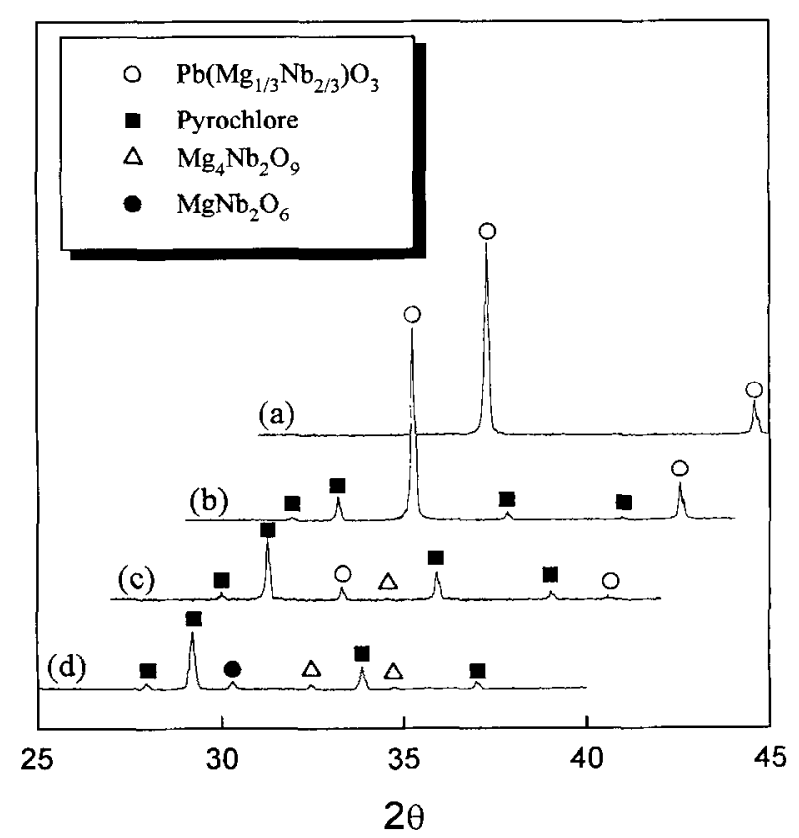

Fig. 1. X-ray diffraction spectra of (a) pure $\mathrm{Pb}\left(\mathrm{Mg}_{1 / 3} \mathrm{Nb}_{2 / 3}\right) \mathrm{O}_{3}$, and $\mathrm{Pb}\left(\mathrm{Mg}_{1 / 3} \mathrm{Nb}_{2 / 3}\right) \mathrm{O}_{3}$ heated at (b) $1200^{\circ} \mathrm{C}$, (c) $1250^{\circ} \mathrm{C}$, and (d) $1300^{\circ} \mathrm{C}$ for $30 \mathrm{~min}$ 


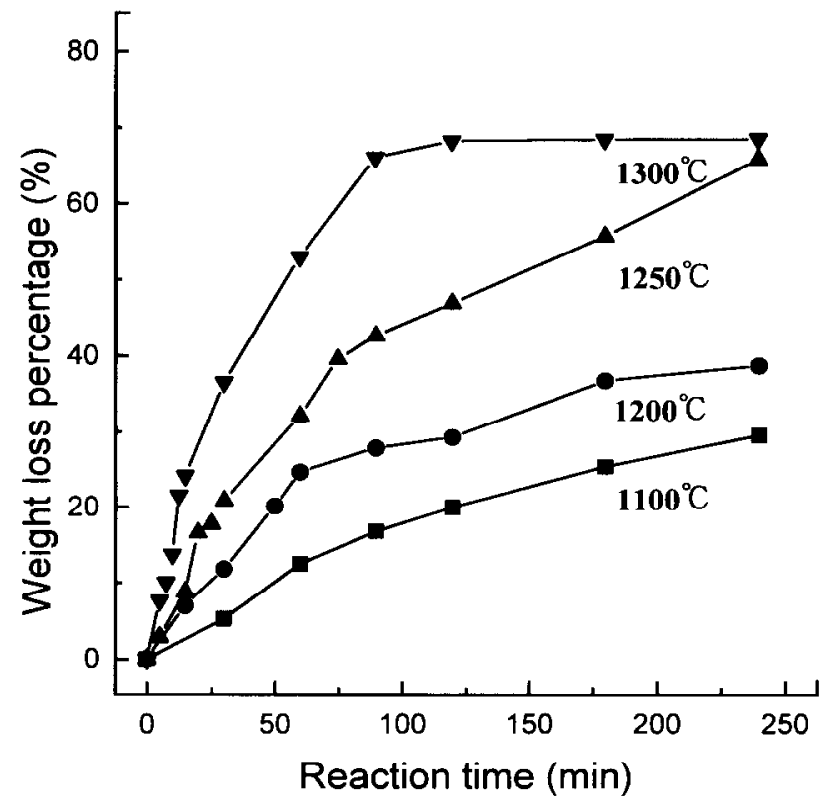

Fig. 2. Weight loss of $\mathrm{Pb}\left(\mathrm{Mg}_{1 / 3} \mathrm{Nb}_{2 / 3}\right) \mathrm{O}_{3}$ as a function of reaction time.

For further investigation on the decomposition behavior of $\mathrm{Pb}\left(\mathrm{Mg}_{1 / 3} \mathrm{Nb}_{2 / 3}\right) \mathrm{O}_{3}$, isothermal heating at $1150^{\circ} \mathrm{C}, 1200^{\circ} \mathrm{C}, 1250^{\circ} \mathrm{C}$, and $1300^{\circ} \mathrm{C}$ for different time was performed. The weight loss and the resultant compounds formed in the heated samples were analyzed. Figure 2 summarizes the weight loss percentage of $\mathrm{Pb}\left(\mathrm{Mg}_{1 / 3} \mathrm{Nb}_{2 / 3}\right) \mathrm{O}_{3}$ powder, under each reaction condition. A substantial weight loss was detected in all heated samples. While heating at $1150^{\circ} \mathrm{C}$, the percentage of weight loss of the samples smoothly increases with increase in reaction time. At $1200^{\circ} \mathrm{C}$, the weight loss percentage increases rapidly until the reaction time reaches $60 \mathrm{~min}$, while after $60 \mathrm{~min}$, the rate of increase in weight loss decreases. This change in the rate of weight loss during reaction implies that the decomposition behavior of the powder is different at the latter stage of reaction, and more than one kind of mechanisms controls the overall decomposition process. As for the variations in wcight loss at $1250^{\circ} \mathrm{C}$, a discontinuity can be observed in this curve. While heating at $1300^{\circ} \mathrm{C}$, the percentage of weight loss saturates after $120 \mathrm{~min}$ of heating. By considering the melting points of the constituent materials in $\mathrm{Pb}\left(\mathrm{Mg}_{1 / 3} \mathrm{Nb}_{2 / 3}\right) \mathrm{O}_{3}$, and the reports in the literature regarding the heating processes of $\mathrm{Pb}\left(\mathrm{Mg}_{1 / 3} \mathrm{Nb}_{2 / 3}\right) \mathrm{O}_{3},{ }^{2,13,25}$ evaporation of $\mathrm{PbO}$ is responsible for the weight loss of the specimens.

The relation between the relative amounts of products formed and reaction time at $1150^{\circ} \mathrm{C}$, $1200^{\circ} \mathrm{C}, 1250^{\circ} \mathrm{C}$, and $1300^{\circ} \mathrm{C}$ are illustrated in Figs 3-6, respectively. Figure 3 indicates that during the initial stage of reaction at $1150^{\circ} \mathrm{C}, \mathrm{Pb}\left(\mathrm{Mg}_{1 / 3^{-}}\right.$ $\left.\mathrm{Nh}_{2 / 3}\right) \mathrm{O}_{3}$ is gradually decomposed, and pyrochlore phase is formed as the product. As the reaction time increases, the amount of pyrochlore phase increases, with a corresponding decrease in the amount of $\mathrm{Pb}\left(\mathrm{Mg}_{1 / 3} \mathrm{Nb}_{2 / 3}\right) \mathrm{O}_{3}$. When the reaction lasts for $180 \mathrm{~min}, \mathrm{~Pb}\left(\mathrm{Mg}_{1 / 3} \mathrm{Nb}_{2 / 3}\right) \mathrm{O}_{3}$ is entirely dccomposed, and only pyrochlore phase now exists in the specimen. At the latter stage of reaction at $1150^{\circ} \mathrm{C}$, the amount of pyrochlore phase starts decreasing slightly and a small amount of $\mathrm{Mg}_{4} \mathrm{Nb}_{2} \mathrm{O}_{9}$ is formed, which implies that pyrochlore phase is also decomposed. Pyrochlore phase is found to be the product of the decomposition of $\mathrm{Pb}\left(\mathrm{Mg}_{1 / 3} \mathrm{Nb}_{2 / 3}\right) \mathrm{O}_{3}$ only. As for $\mathrm{Mg}_{4} \mathrm{Nb}_{2} \mathrm{O}_{9}$, it appears only after the decomposition of $\mathrm{Pb}\left(\mathrm{Mg}_{1 / 3^{-}}\right.$ $\left.\mathrm{Nb}_{2 / 3}\right) \mathrm{O}_{3}$ is completed; therefore, $\mathrm{Mg}_{4} \mathrm{Nb}_{2} \mathrm{O}_{9}$ is

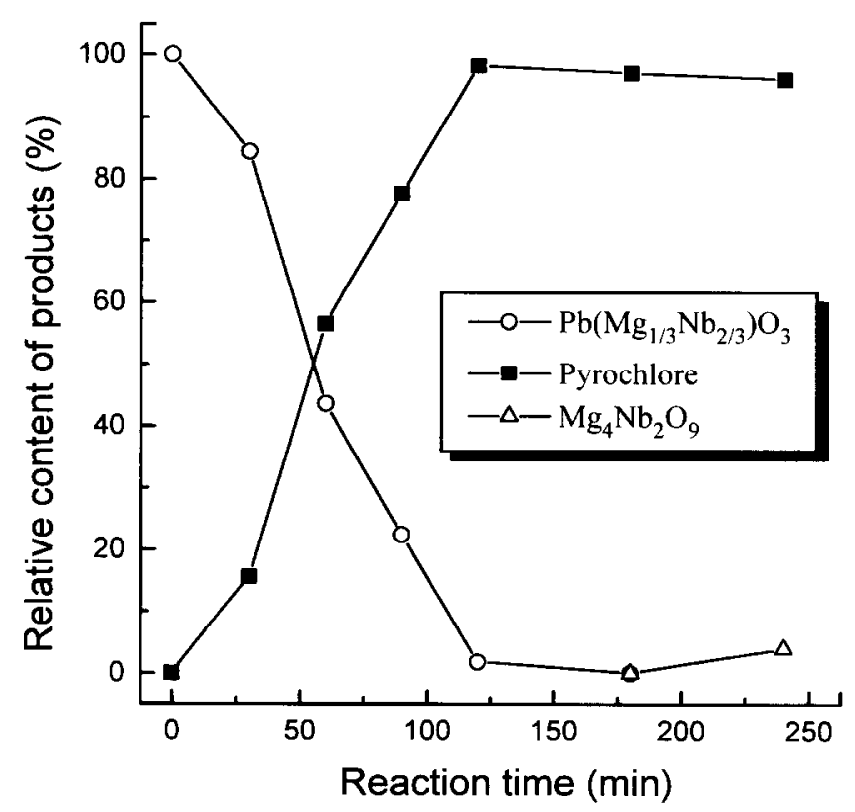

Fig. 3. Variations in the relative contents of products as a function of reaction time during heating of $\mathrm{Pb}\left(\mathrm{Mg}_{1 / 3} \mathrm{Nb}_{2 / 3}\right) \mathrm{O}_{3}$ at $1150^{\circ} \mathrm{C}$. 


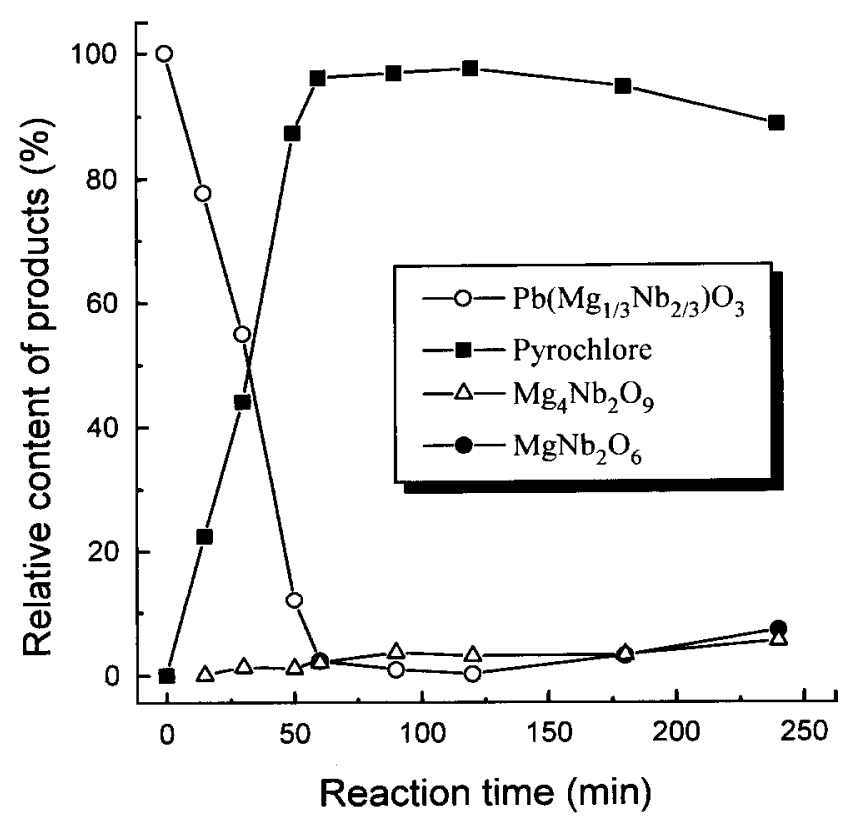

Fig. 4. Variations in the relative contents of products as a function of reaction time during heating of $\mathrm{Pb}\left(\mathrm{Mg}_{1 / 3} \mathrm{Nb}_{2 / 3}\right) \mathrm{O}_{3}$ at $1200^{\circ} \mathrm{C}$.

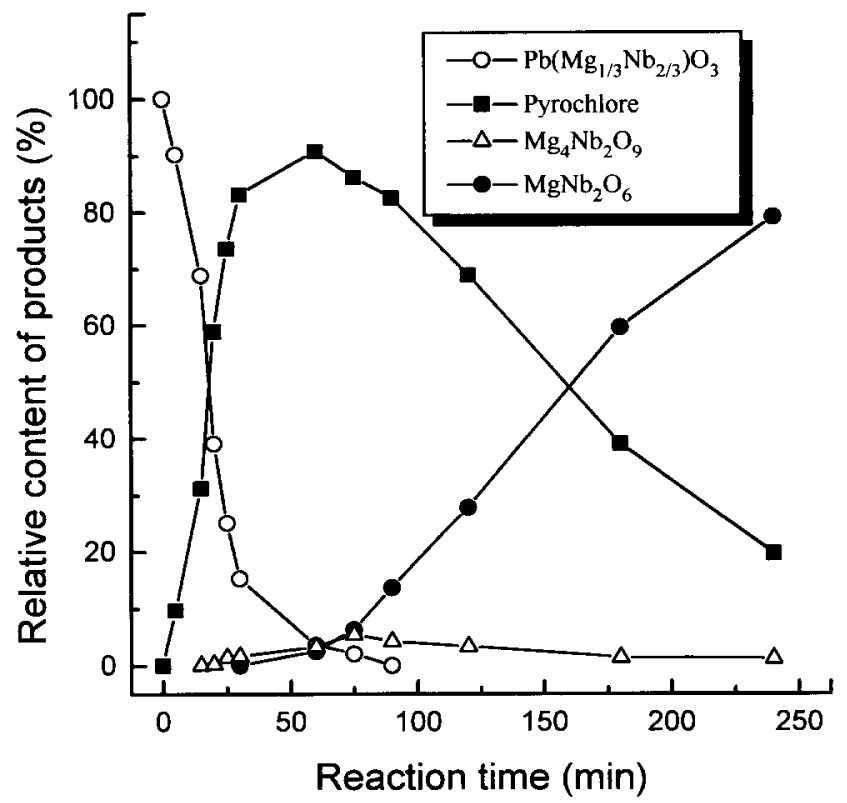

Fig. 5. Variations in the relative contents of products as a function of reaction time during heating of $\mathrm{Pb}\left(\mathrm{Mg}_{1 / 3} \mathrm{Nb}_{2 / 3}\right) \mathrm{O}_{3}$ at $1250^{\circ} \mathrm{C}$.

believed to be the product of the decomposition of pyrochlore phase rather than that of $\mathrm{Pb}\left(\mathrm{Mg}_{1 / 3} \mathrm{Nb}_{2 / 3}\right)-$ $\mathrm{O}_{3}$.

For heating at $1200^{\circ} \mathrm{C}$, the rate of decomposition of $\mathrm{Pb}\left(\mathrm{Mg}_{1 / 3} \mathrm{Nb}_{2 / 3}\right) \mathrm{O}_{3}$ becomes greater than that at $1150^{\circ} \mathrm{C}$ (see Fig. 4). $\mathrm{Pb}\left(\mathrm{Mg}_{1 / 3} \mathrm{Nb}_{2 / 3}\right) \mathrm{O}_{3}$ decomposes completely after reacting for $120 \mathrm{~min}$. Pyrochlore phase is formed at the initial stage of reaction. Besides pyrochlore phase, $\mathrm{Mg}_{4} \mathrm{Nb}_{2} \mathrm{O}_{9}$ also appears at this stage. According to the results in Fig. 3, $\mathrm{Mg}_{4} \mathrm{Nb}_{2} \mathrm{O}_{9}$ is the product generated from decomposition of pyrochlore phase. Therefore, the appearance of $\mathrm{Mg}_{4} \mathrm{Nb}_{2} \mathrm{O}_{9}$ at the initial stage of reaction reveals that the formation and decom- position processes of pyrochlore phase occur simultaneously. The amount of pyrochlore phase reaches maximum at $60 \mathrm{~min}$, and then decreases slightly. At the later stage of reaction, a small amount of $\mathrm{MgNb}_{2} \mathrm{O}_{6}$ is also observed.

The reaction diagram at $1250^{\circ} \mathrm{C}$ is shown in Fig. 5. This graph is obviously different from that in Fig. 4. After $90 \mathrm{~min}, \mathrm{~Pb}\left(\mathrm{Mg}_{1 / 3} \mathrm{Nb}_{2 / 3}\right) \mathrm{O}_{3}$ is completely decomposed. The amount of pyrochlore phase reaches its maximum value at $60 \mathrm{~min}$, and then rapidly decreases. The amount of $\mathrm{Mg}_{4} \mathrm{Nb}_{2} \mathrm{O}_{9}$ reaches a maximum value at $75 \mathrm{~min}$, while the amount of $\mathrm{MgNb}_{2} \mathrm{O}_{6}$ correspondingly increases with decrease in the amount of pyrochlore phase. It 


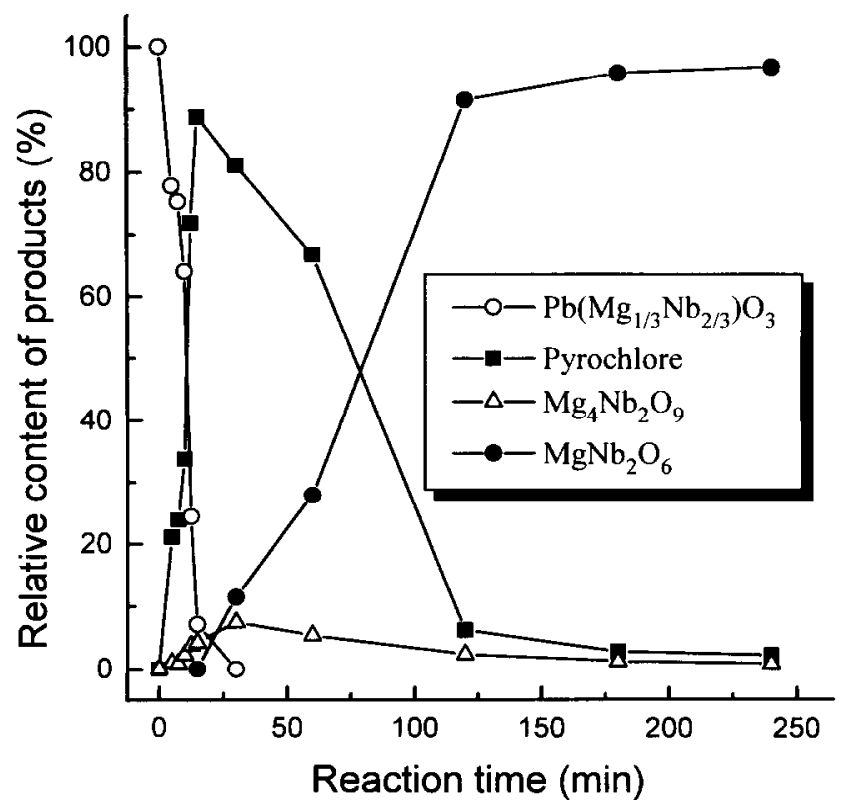

Fig. 6. Variations in the relative contents of products as a function of reaction time during heating of $\mathrm{Pb}\left(\mathrm{Mg}_{1 / 3} \mathrm{Nb}_{2 / 3}\right) \mathrm{O}_{3}$ at $1300^{\circ} \mathrm{C}$.

can be noted that the appearance of $\mathrm{MgNb}_{2} \mathrm{O}_{6}$ occurs later than that of $\mathrm{Mg}_{4} \mathrm{Nb}_{2} \mathrm{O}_{9}$, and the amount of $\mathrm{Mg}_{4} \mathrm{Nb}_{2} \mathrm{O}_{9}$ has a maximum. Therefore, the formation of $\mathrm{MgNb}_{2} \mathrm{O}_{6}$ is considered to be a result of the reaction between $\mathrm{Mg}_{4} \mathrm{Nb}_{2} \mathrm{O}_{9}$ and the residues of the decomposition of pyrochlore phase. This appearance of the maximum amounts of pyrochlore phase as well as $\mathrm{Mg}_{4} \mathrm{Nb}_{2} \mathrm{O}_{9}$ implies that the formation process competes with the consumption process for both compounds. When the consumption rate is greater than the formation rate, the amount of pyrochlore phase or $\mathrm{Mg}_{4} \mathrm{Nb}_{2} \mathrm{O}_{9}$ starts to reduce, and correspondingly, maximum amounts of these phases occur at this condition.

As for the reaction at $1300^{\circ} \mathrm{C}$, the overall characteristics of the reaction diagram are similar to those at $1250^{\circ} \mathrm{C}$. As can be seen from Fig. 6, $\mathrm{Pb}\left(\mathrm{Mg}_{1 / 3} \mathrm{Nb}_{2 / 3}\right) \mathrm{O}_{3}$ is completely decomposed after reacting for $30 \mathrm{~min}$. The amounts of pyrochlore phase and $\mathrm{Mg}_{4} \mathrm{Nb}_{2} \mathrm{O}_{9}$ reach maximum values at $20 \mathrm{~min}$ and $30 \mathrm{~min}$, respectively. At $240 \mathrm{~min}$, only a small amount of pyrochlore phase is left, most of $\mathrm{Mg}_{4} \mathrm{Nb}_{2} \mathrm{O}_{9}$ is consumed, and the major compound is $\mathrm{MgNb}_{2} \mathrm{O}_{6}$. When the reaction is further prolonged to $360 \mathrm{~min}$, pyrochlore phase is entirely dissociated, and $\mathrm{MgNb}_{2} \mathrm{O}_{6}$ is present as the only product. From the EDS analysis, it was found that no lead species existed in this specimen. The weight loss of this specimen was $68.7 \%$. This value is very close to the content of $\mathrm{PbO}$ in stoichiometric $\mathrm{Pb}\left(\mathrm{Mg}_{1 / 3} \mathrm{Nb}_{2 / 3}\right) \mathrm{O}_{3}(68.6 \%)$. Therefore, this confirms that all of $\mathrm{PbO}$ is evaporated from the sample during the decomposition of pyrochlore phase.
3.2 Kinetic analysis of the decomposition reaction of $\mathrm{Pb}\left(\mathrm{Mg}_{1 / 3} \mathrm{Nb}_{2 / 3}\right) \mathrm{O}_{3}$

From the results in Section 3.1, one can notice that at elevated temperatures $\mathrm{Pb}\left(\mathrm{Mg}_{1 / 3} \mathrm{Nb}_{2 / 3}\right) \mathrm{O}_{3}$ thermally decomposes to form pyrochlore phase, which subsequently decomposes to produce $\mathrm{Mg}_{4} \mathrm{Nb}_{2} \mathrm{O}_{9}$. Therefore, two stages of decomposition processes are involved in the thermal treatment of $\mathrm{Pb}\left(\mathrm{Mg}_{1 /}\right.$ $\left.{ }_{3} \mathrm{Nb}_{2 / 3}\right) \mathrm{O}_{3}$. In the following sections, the kinetic analysis of these decomposition processes of $\mathrm{Pb}\left(\mathrm{Mg}_{1 / 3} \mathrm{Nb}_{2 / 3}\right) \mathrm{O}_{3}$ and pyrochlore phase is presented.

For analyzing the kinetics of decomposition of $\mathrm{Pb}\left(\mathrm{Mg}_{1 / 3} \mathrm{Nb}_{2 / 3}\right) \mathrm{O}_{3}$, accurate conversion ratio of $\mathrm{Pb}\left(\mathrm{Mg}_{1 / 3} \mathrm{Nb}_{2 / 3}\right) \mathrm{O}_{3}$ during the decomposition process is required to be calculated. The decomposition ratio of $\mathrm{Pb}\left(\mathrm{Mg}_{1 / 3} \mathrm{Nb}_{2 / 3}\right) \mathrm{O}_{3}$ is denoted as $\mathrm{C}$ $(0 \leq \mathrm{C} \leq 1)$. When $\mathrm{C}$ is equal to zero, it means that $\mathrm{Pb}\left(\mathrm{Mg}_{1 / 3} \mathrm{Nb}_{2 / 3}\right) \mathrm{O}_{3}$ is not decomposed at all, and $\mathrm{Pb}\left(\mathrm{Mg}_{1 / 3} \mathrm{Nb}_{2 / 3}\right) \mathrm{O}_{3}$ is completely decomposed when $C$ is equal to unity. In order to calibrate the effect of weight of samples on the XRD intensity, all samples were mixed with an internal standard, viz. silicon powder. First, equal weights of pure $\mathrm{Pb}\left(\mathrm{Mg}_{1 / 3} \mathrm{Nb}_{2 / 3}\right) \mathrm{O}_{3}$ powder and silicon powder were mixed, and the mixture was analyzed by XRD. From the XRD spectra, the ratio of the intensity of (110) diffraction peak of $\mathrm{Pb}\left(\mathrm{Mg}_{1 / 3} \mathrm{Nb}_{2 / 3}\right) \mathrm{O}_{3}$ to that of the (111) peak of silicon was calculated, and this ratio is defined as $\left(\mathrm{I}_{\mathrm{PMN}} / \mathrm{I}_{\mathrm{Si}}\right)_{0}$. In the above reference sample, the weights of $\mathrm{Pb}\left(\mathrm{Mg}_{1 / 3} \mathrm{Nb}_{2 / 3}\right) \mathrm{O}_{3}$ and silicon were equal. If this reference sample is heated at elevated temperatures, the weight of the decomposed $\mathrm{Pb}\left(\mathrm{Mg}_{1 / 3} \mathrm{Nb}_{2 / 3}\right) \mathrm{O}_{3}$ sample will be less than that of silicon, since the decomposition of $\mathrm{Pb}\left(\mathrm{Mg}_{1 / 3} \mathrm{Nb}_{2 / 3}\right) \mathrm{O}_{3}$ results in weight loss. Therefore, in the heated samples, the weight loss due to decomposition of $\mathrm{Pb}\left(\mathrm{Mg}_{1 / 3} \mathrm{Nb}_{2 / 3}\right) \mathrm{O}_{3}$ has to be calibrated. Therefore, the heated samples were mixed with silicon powder in a weight ratio of $1:(1-\Delta W)$, where $\Delta W$ is the percentage of weight loss percentage of pure $\mathrm{Pb}\left(\mathrm{Mg}_{1 / 3} \mathrm{Nb}_{2 / 3}\right) \mathrm{O}_{3}$ after each heating process. The ratio of the intensity of (110) diffraction peak of $\mathrm{Pb}\left(\mathrm{Mg}_{1 / 3} \mathrm{Nb}_{2 / 3}\right) \mathrm{O}_{3}$ to that of the (111) peak of silicon, defined as $\left(\mathrm{I}_{\mathrm{PMN}} / \mathrm{I}_{\mathrm{Si}}\right)_{\text {i }}$, was then calculated from the XRD spectra of these samples. Using the values of $\left(\mathrm{I}_{\mathrm{PMN}} / \mathrm{I}_{\mathrm{Si}}\right)_{0}$ and $\left(\mathrm{I}_{\mathrm{PMN}} / \mathrm{I}_{\mathrm{Si}}\right)_{\mathrm{i}}$, the decomposition ratio $\mathrm{C}$ of $\mathrm{Pb}\left(\mathrm{Mg}_{1 / 3} \mathrm{Nb}_{2 / 3}\right) \mathrm{O}_{3}$ was calculated by the following equation:

$$
C=1-\left(I_{P M N} / I_{S i}\right)_{i} /\left(I_{P M N} / I_{S i}\right)_{0}
$$

Considering that at certain reaction conditions the decomposition of $\mathrm{Pb}\left(\mathrm{Mg}_{1 / 3} \mathrm{Nb}_{2 / 3}\right) \mathrm{O}_{3}$ occurs simultaneously with that of pyrochlore phase, these two reactions have to be analyzed separately for 
simplifying the kinetic analysis. For the analysis of $\mathrm{Pb}\left(\mathrm{Mg}_{1 / 3} \mathrm{Nb}_{2 / 3}\right) \mathrm{O}_{3}$ decomposition, only the lowtemperature region, wherein most of pyrochlore phase has not decomposed, was considered. Figure 7 illustrates the relationship between the decomposition ratio (C) of $\mathrm{Pb}\left(\mathrm{Mg}_{1 / 3} \mathrm{Nb}_{2 / 3}\right) \mathrm{O}_{3}$ and the reaction time. As can be seen in this figure, the decomposition ratio of $\mathrm{Pb}\left(\mathrm{Mg}_{1 / 3} \mathrm{Nb}_{2 / 3}\right) \mathrm{O}_{3}$ rises monotonously with the reaction time at all the temperatures. Furthermore, the higher the reaction temperature, the faster is the rate of the increase in the decomposition ratios. After heating at $1150^{\circ} \mathrm{C}$ for $60 \mathrm{~min}$, around $70 \%$ of $\mathrm{Pb}\left(\mathrm{Mg}_{1 / 3} \mathrm{Nb}_{2 / 3}\right) \mathrm{O}_{3}$ is decomposed, whereas when the temperature is increased to $1250^{\circ} \mathrm{C}$, heating for only $15 \mathrm{~min}$ results in nearly the same decomposition ratio of $\mathrm{Pb}\left(\mathrm{Mg}_{1 / 3^{-}}\right.$ $\left.\mathrm{Nb}_{2 / 3}\right) \mathrm{O}_{3}$.

At the beginning of the decomposition of $\mathrm{Pb}\left(\mathrm{Mg}_{1 / 3} \mathrm{Nb}_{2 / 3}\right) \mathrm{O}_{3}$, $\mathrm{PbO}$ vaporizes directly from the surface of $\mathrm{Pb}\left(\mathrm{Mg}_{1 / 3} \mathrm{Nb}_{2 / 3}\right) \mathrm{O}_{3}$, and pyrochlore phase is formed around unreacted $\mathrm{Pb}\left(\mathrm{Mg}_{1 / 3} \mathrm{Nb}_{2 / 3}\right)$ $\mathrm{O}_{3}$. Once pyrochlore phase is formed, this phase becomes a barrier for $\mathrm{PbO}$ vaporization. Based on the above mechanism and considering general solid-gas reactions, ${ }^{29}$ three major controlling steps can be envisaged, viz. (1) decomposition reaction at unreacted $\mathrm{Pb}\left(\mathrm{Mg}_{1 / 3} \mathrm{Nb}_{2 / 3}\right) \mathrm{O}_{3}$ surface, (2) diffusion of vaporized $\mathrm{PbO}$ through pyrochlore phase, and (3) diffusion of vaporized $\mathrm{PbO}$ through the gaseous film surrounding the particles. Based on these three controlling processes, the relations between decomposition ratio and reaction time can be obtained. The functions of decomposition ratio and reaction time are expressed as below: ${ }^{29}$

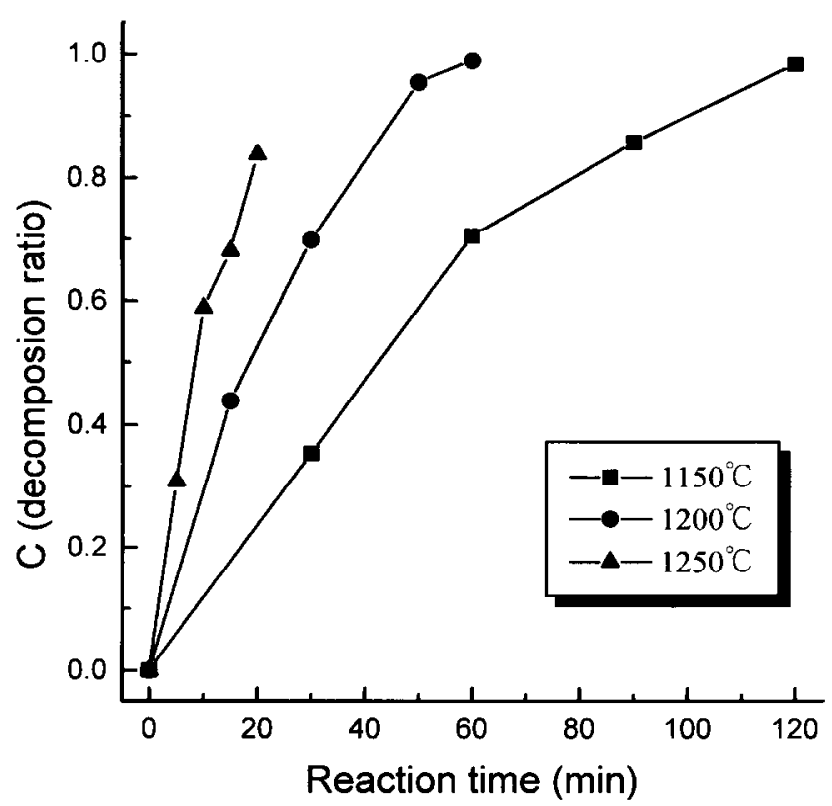

Fig. 7. Decomposition ratio (C) of $\mathrm{Pb}\left(\mathrm{Mg}_{1 / 3} \mathrm{Nb}_{2 / 3}\right) \mathrm{O}_{3}$ as a function of reaction time. (a) Controlled by the chemical reaction

$$
1-(1-C)^{1 / 3}=k t
$$

(b) Controlled by the diffusion of vaporized $\mathrm{PbO}$ through products

$$
1-3(1-C)^{2 / 3}+2(1-C)=k t
$$

(c) Controlled by the diffusion of vaporized $\mathrm{PbO}$ through gaseous film

$$
C=k t
$$

where $C$ is the decomposition ratio of $\mathrm{Pb}\left(\mathrm{Mg}_{1 / 3^{-}}\right.$ $\left.\mathrm{Nb}_{2 / 3}\right) \mathrm{O}_{3}$ and $t$ is the reaction time.

For identifying the rate-controlling step for decomposition of $\mathrm{Pb}\left(\mathrm{Mg}_{1 / 3} \mathrm{Nb}_{2 / 3}\right) \mathrm{O}_{3}$, the decomposition ratios at $1200^{\circ} \mathrm{C}$ were substituted into the above three equations and plotted as a function of reaction time. As illustrated in Fig. 8, only the function $1-(1-C)^{1 / 3}$ displays good linearity with respect to reaction time $(t)$, implying that eqn (3) holds well during the decomposition process. Consequently, this suggests that the rate of decomposition of $\mathrm{Pb}\left(\mathrm{Mg}_{1 / 3} \mathrm{Nb}_{2 / 3}\right) \mathrm{O}_{3}$ is controlled by the rate of chemical reaction rather than the rate of diffusion of vaporized $\mathrm{PbO}$ through pyrochlore phase or gaseous film. Figure 9 shows the curves corresponding to the function of $1-(1-C)^{1 / 3}$ at $1150^{\circ} \mathrm{C}, 1200^{\circ} \mathrm{C}$, and $1250^{\circ} \mathrm{C}$ as a function of reaction time. As can be seen from this figure, all three are linear curves. This result verifies that the ratecontrolling step for the decomposition of $\mathrm{Pb}\left(\mathrm{Mg}_{1 / 3^{-}}\right.$ $\left.\mathrm{Nb}_{2 / 3}\right) \mathrm{O}_{3}$ is the chemical reaction of $\mathrm{Pb}\left(\mathrm{Mg}_{1 / 3} \mathrm{Nb}_{2 / 3}\right)$ $\mathrm{O}_{3}$ itself at the examined temperature range.

According to eqn (3), the reaction rate constant $k$ can be calculated from the slope of each line in Fig. 9. The values of $k$ at 1150,1200 , and $1250^{\circ} \mathrm{C}$ were thus determined to be $6.06 \times 10^{-3}, 1.30 \times 10^{-2}$, and $2.21 \times 10^{-2} \mathrm{~min}^{-1}$, respectively. The activation energy $(E)$ of the reaction was also calculated using Arrhenius's equation:

$$
k=k_{o} \exp (-E / R T)
$$

where $E$ is the activation energy and $T$ is the reaction temperature. From eqn (6), the activation energy of the decomposition of $\mathrm{Pb}\left(\mathrm{Mg}_{1 / 3} \mathrm{Nb}_{2 / 3}\right) \mathrm{O}_{3}$ was calculated to be $234 \mathrm{~kJ} \mathrm{~mol}^{-1}$, and the value of $k_{o}$ as $1.11 \times 10^{8} \mathrm{~min}^{-1}$.

\subsection{Kinetic analysis of the decomposition reaction of pyrochlore phase}

As described in Section 3.1 pyrochlore phase is formed during the decomposition of $\mathrm{Pb}\left(\mathrm{Mg}_{1 / 3} \mathrm{Nb}_{2 / 3}\right)$ $\mathrm{O}_{3}$. At temperatures $\geq 1200^{\circ} \mathrm{C}$, once pyrochlore phase is formed, the formation and decomposition 


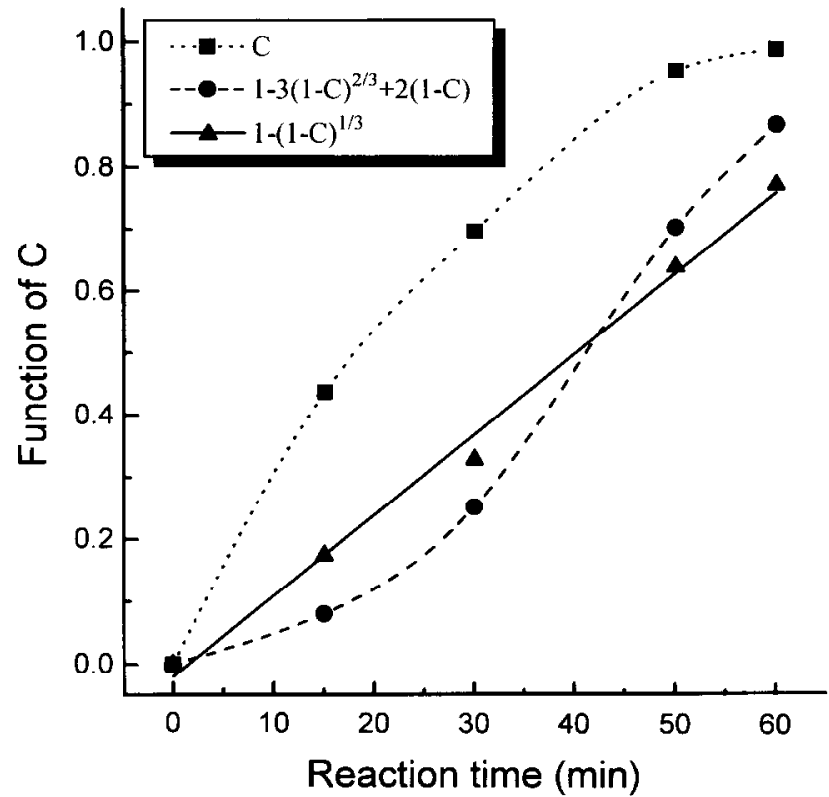

Fig. 8. Function of decomposition ratio $(C)$ versus reaction time for decomposition of $\mathrm{Pb}\left(\mathrm{Mg}_{1 / 3} \mathrm{Nb}_{2 / 3}\right) \mathrm{O}_{3}$.

processes for this phase occur simultaneously. When $\mathrm{Pb}\left(\mathrm{Mg}_{1 / 3} \mathrm{Nb}_{2 / 3}\right) \mathrm{O}_{3}$ is completely consumed, no more pyrochlore phase can be produced, and consequently it continuously decomposes. One can notice that the kinetic analysis in the region after $\mathrm{Pb}\left(\mathrm{Mg}_{1 / 3} \mathrm{Nb}_{2 / 3}\right) \mathrm{O}_{3}$ is entirely consumed can neglect the formation of pyrochlore phase and can simplify the analysis. Based on this concept, the time at which all the $\mathrm{Pb}\left(\mathrm{Mg}_{1 / 3} \mathrm{Nb}_{2 / 3}\right) \mathrm{O}_{3}$ is decomposed is taken as the reference point, and the relative decomposition ratio $(F)$ of pyrochlore phase is defined as a ratio of the content of pyrochlore phase decomposed from the reference point to the content of pyrochlore phase at the reference point.

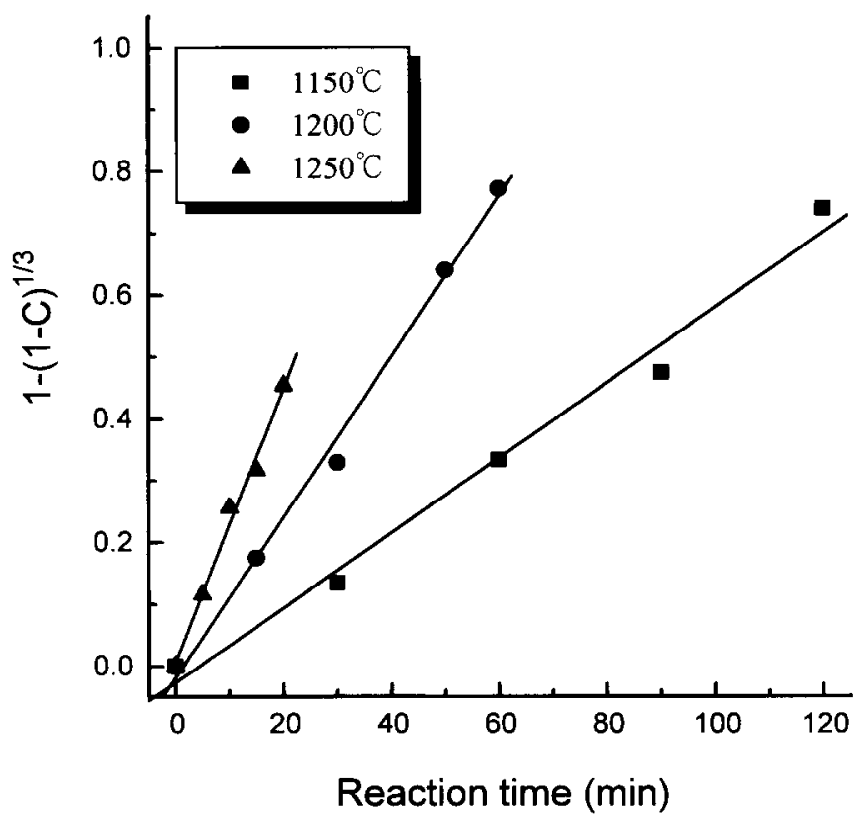

Fig. 9. Plot of $1-(1-C)^{1 / 3}$ versus reaction time for decomposition of $\mathrm{Pb}\left(\mathrm{Mg}_{1 / 3} \mathrm{Nb}_{2 / 3}\right) \mathrm{O}_{3}$.
Similarly, for the analysis of $\mathrm{Pb}\left(\mathrm{Mg}_{1 / 3} \mathrm{Nb}_{2 / 3}\right) \mathrm{O}_{3}$, the decomposed-pyrochlore samples were mixed with standard silicon powder, and the effect of sampled weight on the XRD intensity and loss of weight during decomposition were calibrated. From the XRD spectra, the ratios of the intensity of (222) diffraction peak of pyrochlore phase to that of the (111) peak of silicon at the reference point as well as at certain reaction time were calculated, which are defined as $\left(I_{P Y} / I_{S i}\right)_{0}$ and $\left(I_{P Y} / I_{S i}\right)_{i}$, respectively. Consequently, then the relative decomposition ratio $(F)$ of pyrochlore phase was calculated from the equation written as

$$
F=1-\left(I_{P Y} / I_{S i}\right)_{i} /\left(I_{P Y} / I_{S i}\right)_{0}
$$

The relations between the decomposition ratio of pyrochlore phase and the reaction time are presented in Fig. 10. Since pyrochlore phase does not decompose at $1150^{\circ} \mathrm{C}$, no data at $1150^{\circ} \mathrm{C}$ are shown in this figure. As the decomposition behavior of $\mathrm{Pb}\left(\mathrm{Mg}_{1 / 3} \mathrm{Nb}_{2 / 3}\right) \mathrm{O}_{3}$, the decomposition ratio of pyrochlore phase increases monotonously at all three temperatures $\left(1200^{\circ} \mathrm{C}, 1250^{\circ} \mathrm{C}\right.$, and $\left.1300^{\circ} \mathrm{C}\right)$ with reaction time as well as reaction temperature. However, during the dccomposition of pyrochlore phase, the microstructures of samples vary rapidly. A representative SEM micrograph of the decomposed pyrochlore phase $\left(1200^{\circ} \mathrm{C}\right.$ for $\left.90 \mathrm{~min}\right)$ is compared with that of pure $\mathrm{Pb}\left(\mathrm{Mg}_{1 / 3} \mathrm{Nb}_{2 / 3}\right) \mathrm{O}_{3}$ in Fig. 11. As can be seen from this figure, the decomposed pyrochlore phase exhibits a molten texture. Notably, this kind of texture was not found during decomposition of $\mathrm{Pb}\left(\mathrm{Mg}_{1 / 3} \mathrm{Nb}_{2 / 3}\right) \mathrm{O}_{3}$.

Observing the SEM micrographs, one can realize that decomposition of pyrochlore phase occurs in a molten-state rather in a powder state. Therefore, the decomposition reaction for pyrochlore phase is believed to belong to the $n$th order reaction. If the decomposition of pyrochlore phase is assumed to be a first-order reaction $(n=1)$, then the relation between the relative decomposition ratio $(F)$ and reaction time $(t)$ can be expressed as

$$
-\ln (1-F)=k_{p} t
$$

where $t$ is the reaction time and $k_{P}$ is the reaction rate constant. The values of $-\ln (1-F)$ at 1200 , 1250 , and $1300^{\circ} \mathrm{C}$ are plotted as a function of reaction time in Fig. 12, which yields three straight lines. This result confirms that the decomposition of pyrochlore phase is a first-order reaction. From the slopes of the lines in Fig. 11, the rate constants $k_{p}$ at 1200,1250 , and $1300^{\circ} \mathrm{C}$ were determined to 


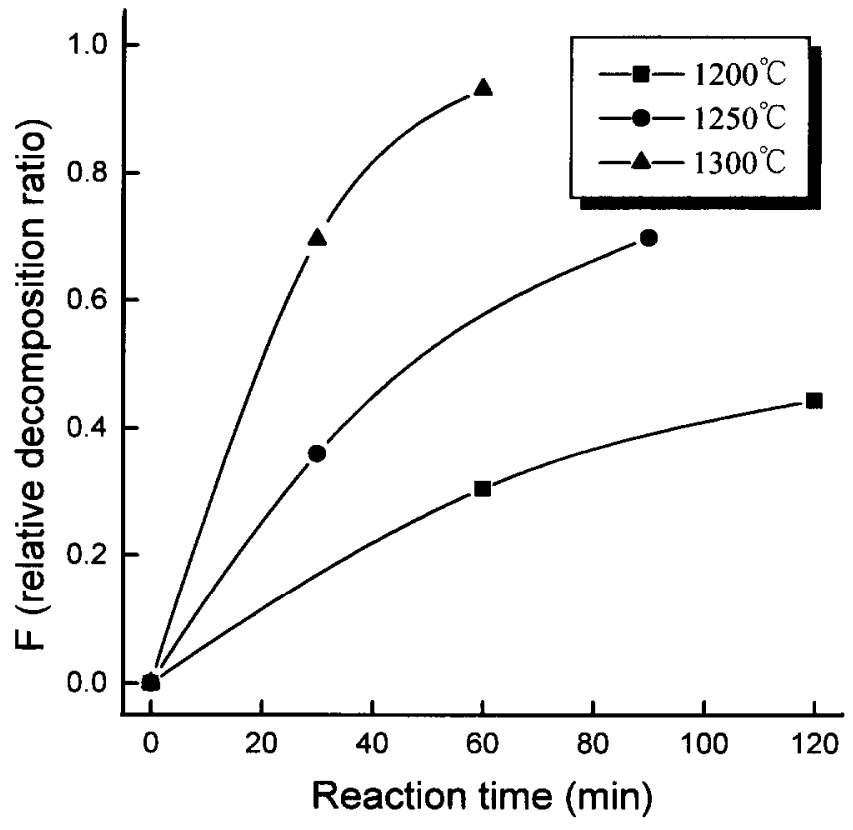

Fig. 10. Relative decomposition ratio $(F)$ of pyrochlore phase as a function of reaction time.

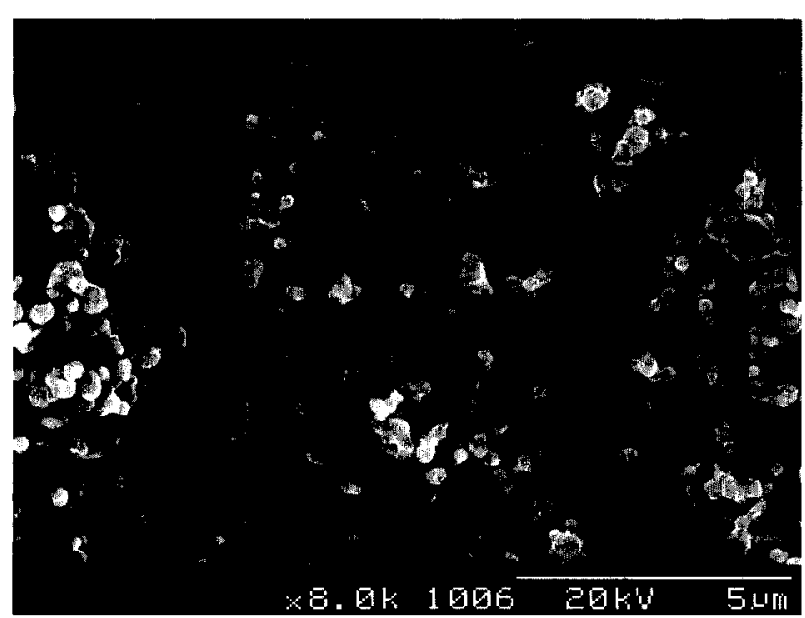

(a)

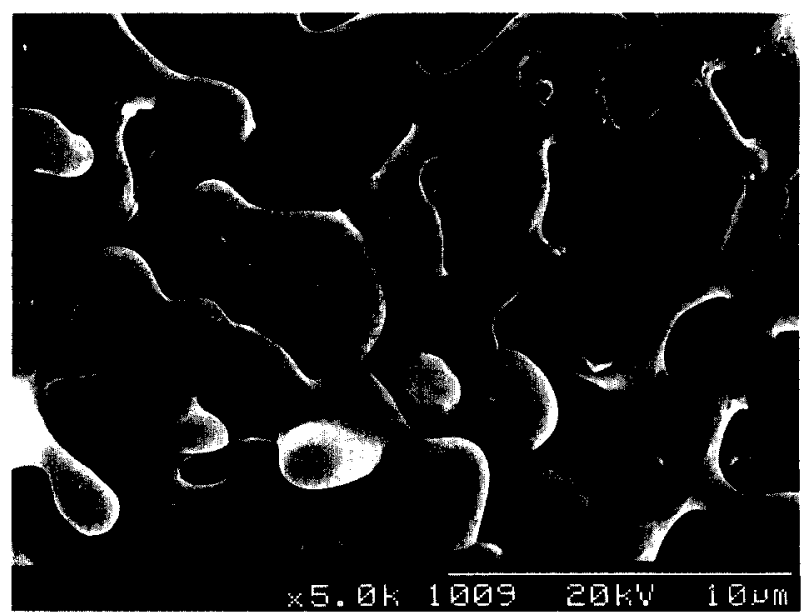

(b)

Fig. 11. Scanning electron micrographs of (a) pure $\mathrm{Pb}\left(\mathrm{Mg}_{1 / 3^{-}}\right.$ $\left.\mathrm{Nb}_{2 / 3}\right) \mathrm{O}_{3}$ and (b) $\mathrm{Pb}\left(\mathrm{Mg}_{1 / 3} \mathrm{Nb}_{2 / 3}\right) \mathrm{O}_{3}$ heated at $1200^{\circ} \mathrm{C}$ for $90 \mathrm{~min}$. be $4.88 \times 10^{-3}, 1.32 \times 10^{-2}$, and $4.03 \times 10^{-2} \mathrm{~min}^{-1}$, respectively. According to the Arrhenius equation, the natural $\log$ of $k_{P}$ was plotted versus the reciprocal of reaction temperature, and from the value of the corresponding slope, the activation energy for decomposition of pyrochlore phase was determined to be $407 \mathrm{~kJ} \mathrm{~mol}^{-1}$, and the value of $k_{o}$ as $1.23 \times 10^{12} \mathrm{~min}^{-1}$.

The above results confirm that decomposition of $\mathrm{Pb}\left(\mathrm{Mg}_{1 / 3} \mathrm{Nb}_{2 / 3}\right) \mathrm{O}_{3}$ and that of pyrochlore phase are controlled by different mechanisms. It can be also noted that the activation energy for decomposition of pyrochlore phase is significantly higher than that of $\mathrm{Pb}\left(\mathrm{Mg}_{1 / 3} \mathrm{Nb}_{2 / 3}\right) \mathrm{O}_{3}$. During general serial reactions, change in the reaction rate would be more sensitive to the increase in temperature for a reaction with higher activation energy. Therefore, the above description is consistent with the fact that increase in reaction temperature has a more pronounced effect on the decomposition process of pyrochlore phase than that of $\mathrm{Pb}\left(\mathrm{Mg}_{1 / 3} \mathrm{Nb}_{2 / 3}\right) \mathrm{O}_{3}$.

\section{Conclusions}

The decomposition processes of ferroelectric $\mathrm{Pb}\left(\mathrm{Mg}_{1 / 3} \mathrm{Nb}_{2 / 3}\right) \mathrm{O}_{3}$ powder at elevated temperatures have been examined. During the decomposition of $\mathrm{Pb}\left(\mathrm{Mg}_{1 / 3} \mathrm{Nb}_{2 / 3}\right) \mathrm{O}_{3}$, pyrochlore phase is formed and a large amount of $\mathrm{PbO}$ is evaporated, which results in a substantial weight loss. The pyrochlore phase is subsequently dissociated, during which $\mathrm{Mg}_{4} \mathrm{Nb}_{2} \mathrm{O}_{9}$ and $\mathrm{MgNb}_{2} \mathrm{O}_{6}$ are produced. The decomposition processes of $\mathrm{Pb}\left(\mathrm{Mg}_{1 / 3} \mathrm{Nb}_{2 / 3}\right) \mathrm{O}_{3}$ and pyrochlore phase are accelerated with increase

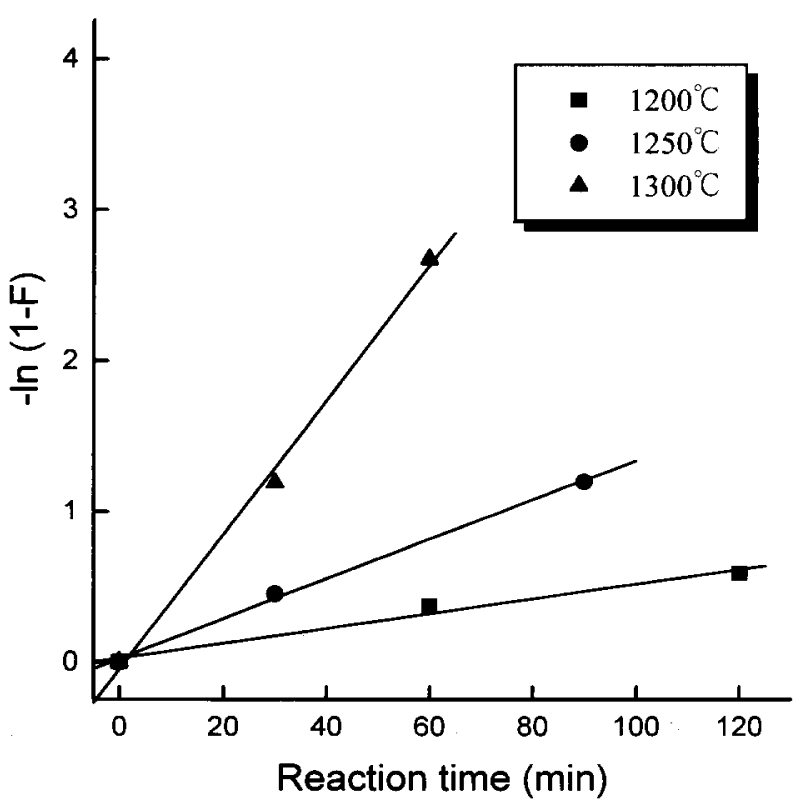

Fig. 12. Plot of $-\ln (1-F)$ versus reaction time for decomposition of pyrochlore phase. 
in reaction temperature as well as reaction time. From the isothermal analysis of reaction kinetics, the decomposition of $\mathrm{Pb}\left(\mathrm{Mg}_{1 / 3} \mathrm{Nb}_{2 / 3}\right) \mathrm{O}_{3}$ is shown to be controlled by the chemical reaction of $\mathrm{Pb}\left(\mathrm{Mg}_{1 / 3} \mathrm{Nb}_{2 / 3}\right) \mathrm{O}_{3}$ itself, with activation energy of $234 \mathrm{~kJ} \mathrm{~mol}^{-1}$. When pyrochlore phase is decomposed, a molten microstructure is formed. Furthermore, the reaction kinetics for pyrochlore phase decomposition is a first-order reaction with higher activation energy of $407 \mathrm{~kJ} \mathrm{~mol}^{-1}$.

\section{References}

1. Uchino, K., Nomura, S., Cross, L. E., Jang, S. J. and Newnham, R. E., Electrostrictive effect in lead magnesium niobate single crystal. J. Appl. Phys., 1980, 51(2), 1142-1145.

2. Lejeune, M. and Boilot, J. P., Influence of ceramic processing on dielectric properties of perovskite type compound: $\mathrm{Pb}\left(\mathrm{Mg}_{1 / 3} \mathrm{Nb}_{2 / 3}\right) \mathrm{O}_{3}$. Ceram. Inter., 1983, 9(4), 119-122.

3. Chen, J., Gorton, A., Chan, H. M. and Harmer, M., Effect of powder purity and second phases on the dielectric properties of lead magnesium niobate ceramics. $J$. Am. Ceram. Soc., 1986, 69(12), C303.

4. Guha, J. P., Wong, D. J. and Anderson, H. U., Effect of excess $\mathrm{PbO}$ on the sintering characteristics and dielectric properties of $\mathrm{Pb}\left(\mathrm{Mg}_{1 / 3} \mathrm{Nb}_{2 / 3}\right) \mathrm{O}_{3}-\mathrm{PbTiO}_{3}$ based ceramics. J. Am. Ceram. Soc., 1988, 71(3), C152.

5. Yan, M. F., Ling, H. C. and Rhodes, W. W., Preparation and properties of $\mathrm{PbO}-\mathrm{MgO}-\mathrm{Nb}_{2} \mathrm{O}_{5}$ ceramics near the $\mathrm{Pb}\left(\mathrm{Mg}_{1 / 3^{-}}\right.$ $\left.\mathrm{Nb}_{2 / 3}\right) \mathrm{O}_{3}$ composition. J. Mater. Res., 1989, 4(4), 930-944.

6. Papet, P., Dougherty, J. P. and Shrout, T. R., Particle and grain size effects on the dielectric behavior of the relaxor ferrnelectric $\mathrm{Pb}\left(\mathrm{Mg}_{1 / 3} \mathrm{Nb}_{2 / 3}\right) \mathrm{O}_{3}$. J. Mater, Res., 1990, 5(12), 2902-2909.

7. Pilgrim, S. M., Massuda, M. and Sutherland, A. E., Electromechanical determination of the high-field phase transformation of $\mathrm{Pb}\left(\mathrm{Mg}_{1 / 3} \mathrm{Nb}_{2 / 3}\right) \mathrm{O}_{3}-\mathrm{PbTiO}_{3}-(\mathrm{Ba}, \mathrm{Sr}) \mathrm{TiO} 3$ relaxor ferroelectrics. J. Am. Ceram. Soc., 1992, 75(7), 1970-1974.

8. Kanai, H., Furukawa, O., Nakamura, S. I. and Yamashita, Y., Effect of stoichiometry on dielectric properties and life performance of $\left(\mathrm{Pb}_{0.875} \mathrm{Ba}_{0.125}\right)\left[\left(\mathrm{Mg}_{1 / 3} \mathrm{Nb}_{2 / 3}\right)_{0.5}\right.$ $\left.\left(\mathrm{Zn}_{1 / 3} \mathrm{Nb}_{2 / 3}\right)_{0.3} \mathrm{Ti}_{0.2}\right] \mathrm{O}_{3}$ relaxor dielectric ceramic: part $\mathrm{I}$, dielectric properties. J. Am. Ceram. Soc., 1993, 76(2), 454-458

9. Randall, C. A., Hilton, A. D., Barber, D. J. and Shrout, T. R., Extrinic contributions to the grain size dependence of relaxor ferroelectric $\mathrm{Pb}\left(\mathrm{Mg}_{1 / 3} \mathrm{Nb}_{2 / 3}\right) \mathrm{O}_{3}: \mathrm{PbTiO}_{3}$ ceramics. J. Mater. Res., 1993, 8(4), 880-884.

10. Liou, Y. C. and $\mathrm{Wu}, \mathrm{L}$., Effect of heating rate on the dielectric properties of PMN-PT relaxor ceramics. J. Am. Ceram. Soc., 1994, 77(12), 3255-3258.

11. Sato, Y., Kanai, H. and Yamashita, Y., Effect of silver and palladium doping on the dielectric properties of $0.9 \mathrm{~Pb}\left(\mathrm{Mg}_{1 / 3} \mathrm{Nb}_{2 / 3}\right) \mathrm{O}_{3}-\mathrm{PbTiO}_{3}$. J. Am. Ceram. Soc., 1996, 79(1), 261-265.
12. Inada, M., Analysis of the formation process of the piezoelectric PCM ceramics. Jpn. Natl. Tech. Report, 1977, 23(1), 95-102.

13. Lejeune, M. and Boilot, J. P., Formation mechanism and ceramic process of the ferroelectric perovskites: $\mathrm{Pb}\left(\mathrm{Mg}_{1 / 3}\right.$ $\left.\mathrm{Nb}_{2 / 3}\right) \mathrm{O}_{3}$ and $\mathrm{Pb}\left(\mathrm{Fe}_{1 / 2} \mathrm{Nb}_{1 / 2}\right) \mathrm{O}_{3}$. Ceram. Inter., 1982, 8(3), 99-103.

14. Swartz, S. L. and Shrout, T. R., Fabrication of perovskite lead magnesium niobate. Mater. Res. Bull., 1982, 17, 1245-1250.

15. $\mathrm{Lu}, \mathrm{C}$. $\mathrm{H}$. and Lee, J. T., Influence of columbite $\mathrm{MgNb}_{2} \mathrm{O}_{6}$ on the perovskite formation and microstructure of $\mathrm{Pb}\left(\mathrm{Mg}_{1 / 3} \mathrm{Nb}_{2 / 3}\right) \mathrm{O}_{3}$. J. Ceram. Soc. Jpn., 1995, 103(11), $1122-1128$.

16. Watanabe, A., Haneda, H., Moriyoshi, Y., Shirasaki, S., Kuramoto, S. and Yamamura, H., Preparation of lead magnesium niobate by a coprecipitation method. $J$. Mater. Sci., 1992, 27(5), 1245-1249.

17. Guzman, G., Aegerter, M. A., Barboux, P. and Livage, J., Synthesis of ferroelectric perovskite through aqueous-solution techniques. J. Mater. Sci., 1993, 28(23), 6510-6515.

18. Chaput, F., Boilot, J. P., Lejeune, M., Papiernik, R. and Hubert-Pfalzgraf, L. G., Low-temperature route to lead magnesium niobate. J. Am. Ceram. Soc., 1988, 72(8), 1335-1357.

19. Francis, L. F., OH, Y. J. and Payne, D. A., Sol-Gel processing and properties of lead magnesium niobate powders and thin layers. J. Mater. Sci., 1990, 25(12), 5007-5013.

20. Katayama, H., Abe, M. and Akiba, T., Preparation of $\mathrm{Pb}\left(\mathrm{Mg}_{1 / 3} \mathrm{Nb}_{2 / 3}\right) \mathrm{O}_{3}$ powder by molten salt method. Ceram. Inter., 1989, 15(5), 289-295.

21. Yoon, K. H., Cho, Y. S., Lee, D. H. and Kang, D. H., Powder characteristics of $\mathrm{Pb}\left(\mathrm{Mg}_{1 / 3} \mathrm{Nb}_{2 / 3}\right) \mathrm{O}_{3}$ prepared by molten salt synthesis. J. Am. Ceram. Soc., 1993, 76(5), 1373-1376.

22. Yanagisawa, $\mathrm{K}$., Formation of perovskite-type $\mathrm{Pb}\left(\mathrm{Mg}_{1 / 3^{-}}\right.$ $\left.\mathrm{Nb}_{2 / 3}\right) \mathrm{O}_{3}$ under hydrothermal conditions. J. Mater. Sci. Lett., 1993, 12(23), 1842-1843.

23. Chen, J. and Harmer, M. P., Microstructure and dielectric properties of lead magnesium niobate-pyrochlore diphasic mixtures. J. Am. Ceram. Soc., 1990, 73(1), 68-73.

24. $\mathrm{Lu}, \mathrm{C} . \mathrm{H}$. and Huang, W. S., Role of the addition of $\mathrm{Pb}\left(\mathrm{Li}_{1 / 1} \mathrm{Fe}_{1 / 4} \mathrm{~W}_{1 / 2}\right) \mathrm{O}_{3}$ in the low-temperature sintering and dielectric characteristics of $\mathrm{Pb}\left(\mathrm{Mg}_{1 / 3} \mathrm{Nb}_{2 / 3}\right) \mathrm{O}_{3}$ ceramics. $J$. Ceram. Soc. Jpn., 1996, 104(7), 587-593.

25. Kim, B. H., Sakurai, O., Wakiya, N. and Mizutani, N., Effect of atmosphere on stability of $\mathrm{Pb}\left(\mathrm{Mg}_{1 / 3} \mathrm{Nb}_{2 / 3}\right) \mathrm{O}_{3}$ (PMN) ceramics. Mater. Res. Bull., 1997, 32(4), 451-459.

26. Wakiya, N., Ishizawa, N., Saiki, A., Shiniozaki, K. and Mizutani, N., Composition range of cubic pyrochlore type compound in lead-magnesium-niobium-oxygen system. $J$. Ceram. Soc. Jpn., 1994, 102(6), 612-615.

27. I ejeune, M. and Boilot, J. P., Optimization of dielectric properties of lead-magnesium niobate ceramics. Am. Ceram. Soc. Bull., 1985, 64(4), 679-682.

28. Guha, J. P. and Anderson, H. U., Microstructural inhomogeneity in sintered $\mathrm{Pb}\left(\mathrm{Mg}_{1 / 3} \mathrm{Nb}_{2 / 3}\right) \mathrm{O}_{3}-\mathrm{PbTiO}_{3}$ based ceramics. J. Am. Ceram. Soc., 1987, 70(3), C39.

29. Levenspiel O., Chemical Reaction Engineering. John Wiley \& Sons, New York, 1972, pp. 357-371. 